\title{
Evaluation on the Application of Stratified Double Net Cages for Freshwater Fish Aquaculture: Macrobenthic Assemblages as Bioindicator
}

\author{
Sapto P. Putro ${ }^{1}$, Agung Sudaryono ${ }^{2}$, Widowati $^{1}$, and Suhartana ${ }^{1}$ \\ ${ }^{I}$ Department of Biology, Faculty of Sciences and Mathematics, Diponegoro University, Semarang, Indonesia \\ Email: saptoputro@gmail.com; widowatimath@undip.ac.id; suhartanagi_putra@yahoo.com \\ ${ }^{2}$ Aquaculture Study Program, Diponegoro University, Semarang, Indonesia \\ Correspoindace ti : agungsoed@yahoo.co.id
}

\begin{abstract}
Sapto P. Putro, Agung Sudaryono, Widowati, and Suhartana. 2014. Evaluation on the Application of Stratified Double Net Cages for Freshwater Fish Aquaculture: Macrobenthic Assemblages as Bioindicator. Aquacultura Indonesiana, 15 (1) : 7-13. Various designs of floating fish cages have been developed by the fishermen, both for applications on the rivers, reservoirs, coastal areas, offshore and lakes. In order to optimise the ecological use of Lake Rawapening as fish farming area, it is necessary to change the design of cages as well as farming practice. The development of design of floating net cage has been done using Stratified Double Net Cages (SDNC), and it is considered to be one of the best alternatives to solve the problem. The aims of this study were to evaluate the application of Stratified Double Net Cages (SDNC) based on macrobenthic assemblages to assess the potential environmental impact caused by farming activities using SDNC. The results were compared to the reference areas, which were 1 (one) $\mathrm{km}$ away from the farming zones. This study was carried out at the ficinity areas of two SDNC. The cages were operated by fisherman groups of Ngudi Makmur and Rukun Santosa, located on the water column of Lake Rawapening, close to Asinan District, Central Java. The results showed that the composition of species macrobenthic assemblages between farming sites and control sites were different both in number and compotition, indicating the initial stage of disturbance caused by organic enrichment due to farming actitivites. The study provides important implications for the arrangement of Stratified Double Net Cage (SDNC) activities at Lake Rawapening, both in density and ordinate position in order to maintain the ecological function of this lake.
\end{abstract}

Keywords: Stratified Double Net Cages (SDNC); Lake Rawapening; Macrobenthic assemblages; Opportunistic taxa; Sedimentation

\section{Introduction}

Lake Rawapening is an area that has great potential, especially as the area of aquaculture. In the last decade, fish farming in the form of floating net cages had grown rapidly in the region. Despite the benefits of this activity, ecological disturbance of Lake Rawapening region was likely to occur, especially at the areas of upstream and downstream. The main problem of the lake was due to high rate of sedimentation and organic enrichment both in the water and sediment (Putro and Suhartana, 2008). Utilization of Lake Rawapening as area of fish farming in the form of traditional net cage system has been developed by local people since 1997 (Zaenuri, Head of Asinan Village, personal communication). The results of the preliminary survey in the region indicated an organic enrichment, characterized by rapid population growth of water weeds, especially Eichornia crassipes, Hydrilla sp. and Typha sp. which covered a half of the water surface. Without the application of good environmental management, the organic materials generated from the cage aquaculture activities may cause an ecological disturbance in the region, thus threatening the sustainability of its business. One of the animals that may be affected by the presence of organic enrichment of sediments is macrobenthic assemblages.

Various designs of floating fish cages have been developed by the fishermen, both for applications on the rivers, reservoirs, coastal areas, offshore and lakes. So far, the design of cages tend to be orientated to be installed horizontally of the high density fish cages. Unfortunately, in line with the time, the number of cages tend to grow horizontally on the water column. This situation will affect the water current and environmental balance, especially when they are applied to the slow water current aquatic environment. In order to 
optimise the ecological use of Lake Rawapening as fish farming area, it is necessary to change the design of cages as well as farming practice. Based on these conditions, the development of design of floating net cage has been done using Stratified Double Net Cages (SDNC) (Putro and Suhartana, 2008; Putro et al., 2010). The SDNC is considered to be one of the best alternatives to solve the problem. The advantage of this system is that manufacturing process is much easier using simple materials, so the installation process wil be easier and economical. Floating cage system is suitable for aquatic areas affected by water tidal because when they lift up and down to follow the horizontal water level. The aims of this study were to evaluate the application of Stratified Double Net Cages (SDNC) based on macrobenthic assemblages to assess the potential environmental impact caused by the use of SDNC farming activities.

\section{Material and Method}

Sampling stations were located at Lake Rawapening, Semarang Regency, Central Java. Location I was at the area of Stratified Double Net Cages (SDNC) belong to 'Rukun Santosa' which has been operating for a year and been fallowed for some time. Location II was located in an area of Stratified Double Net Cages (SDNC) 'Ngudi Makmur', which is relatively new in its operation, while location III was a reference site that was $1 \mathrm{~km}$ away from the area of the farming sites. Each location had 3 stations with 3 replicates. Sampling procedures included collecting sediments, fixation, rinsing, sorting, preservation, and identification. Sediment was analysed for sediment grain size (SGS), and total organic content (TOC).

Two-way analysis of variance (ANOVA) was used to compare the results of measurements of physical parameters and the sediment-water chemistry between locations and times of sampling. Data were tested using KolmogorovSmirnov test for normal distribution of the data and Levene test for homogeneity of variance. Further post hoc test using Tukey HSD performed to further compare the results of the analysis showed a significant difference $(P<0.05)$. Multivariate analysis using the Principal Component Analysis (PCA) with Euclidean distance performed to describe differences in environmental variability between sampling locations. While multivariate analysis using non-metric Multi Dimensional Scaling
(NMDS) using Bray-Curtis similarity was performed to the data macrobenthos to describe the differences between the location and time of sampling. Further analysis using the BEST-BIOENV was conducted to determine the correlation between abiotic factors (physical and chemical parameters of water and sediments) that influence the structure of macrobenthos (biotic factors) (Clarke and Warwick, 2001; Clarke and Gorley, 2006). Non-parametric test used is the index of species diversity and similarity indices, i.e. Shannon-Wiener diversity index (H '), and the similarity index of Pielou's Evenness $\left(\mathrm{J}^{\prime}\right)$.

\section{Result and Discussion}

In general, the quality of waters in the three sampling locations was considered as within the normal range, for instance the mean of dissolved oxygen ( 5.0 to $8.0 \mathrm{mg} / \mathrm{L}), \mathrm{pH}$ (5.8 to 9.7), turbidity (15.8 - 57.3 NTU), conductivity $(0.2-0.3 \mathrm{mS} / \mathrm{cm})$, temperature $\left(27.0\right.$ to $31.0^{\circ} \mathrm{C}$ ), and water clarity $(34.3$ to $66.3 \mathrm{~cm}$ ). The $\mathrm{pH}$ showed no significant differences between sampling locations, but between the times of sampling $[\mathrm{F}(2,15)=$ $29.69, p=0.001]$. Further post hoc test using Tukey HSD showed significant differences in the average $\mathrm{pH}$ value between the time of sampling in July $(F=8: 43, S D=0.15)$ and December $(F=6.70, S D=1: 01)$, and between July and October $(\mathrm{M}=9: 40, \mathrm{SD}=0.28)$. The dissolved oxygen (DO) values between sampling sites showed no significant difference, but between the time of sampling $[\mathrm{F}(2,15)=4: 53, \mathrm{P}=0.029]$. Further post hoc test using Tukey HSD showed significant differences in the average value of DO between the July sampling period $(\mathrm{M}=5217$, $\mathrm{SD}=0232)$ and December $(\mathrm{F}=6.95, \mathrm{SD}=$ 1.61). The ANOVA results indicated no significant difference in temperature between sampling locations, but between the time of sampling $[\mathrm{F}(2,15)=6: 35, \mathrm{P}=0.010]$. Further post hoc test using Tukey HSD showed significant differences in the average temperature value between the time of sampling in July $(\mathrm{F}=07.26, \mathrm{SD}=0558)$ and December $(\mathrm{F}=28.73, \mathrm{SD}=1.70)$. Water clarity has no significant difference between sampling locations, but between the times of sampling $[\mathrm{F}(2,15)=10937, \mathrm{P}=0.001]$. Further post hoc test using Tukey HSD 
showed significant differences in the average value of water clarity levels between the time of sampling in July $(\mathrm{F}=58.5, \mathrm{SD}=6.05)$ and December $(F=40.43, S D=2.5)$, and between July and October $(F=45.4, S D=10.01)$.

Water current in the vicinity of the Tuntang River as the discharge of flow rate (outlet) of Lake Rawapening exhibited slightly weaker than the control site or the middle of the lake $(16 \mathrm{~cm} / \mathrm{sec})$, with average of $12.5 \mathrm{~cm} / \mathrm{sec}$. The increasing number of fish cage installation was likely to be a major cause of weakening the water currents in the area. However, the water currents were within the range which was still possible to create either dissolved or sedimented organic matter move from the source (farming activities), thus reducing the risk of organic material accumulated under the farms (Putro et al., 2006). The composition of sediment in both the location of fish cages and control site was dominated by coarse sand (42-47\%) and fine sand $(26-36 \%)$. This indicates that the overall activity of Stratified Double Net Cage (SDNC) did not significantly affect the structure of the surrounding sediment grain size. Results of measurement of organic content of the substrate at location I (Rukun Santosa's cages) ranged from 14.2 to $14.76 \mathrm{mg} / \mathrm{g}$, whereas in location II (Ngudi Makmur's cages) ranged from 14.17 to $16.2 \mathrm{mg} / \mathrm{g}$. This amount was slightly lower than the content in a location III ranged from 19.12 to $22.88 \mathrm{mg} / \mathrm{g}$. Those indicated the organic matter derived mainly from the decomposition of dead aquatic plants, especially water hyacinth, compared to that originating from aquaculture activities. Another possibility was excess of aquaculture activities (unfed pellets and fish feces) has been shifted or carried away by strong currents around it so it could reach areas that was not used for farming.

The average of heavy metal content in the sediments at the location of farming exhibited the highest levels for $\mathrm{Fe}$, which valued at $427.44 \mathrm{mg} / \mathrm{L}$, whereas $\mathrm{Pb}$ and $\mathrm{Cu}$ content were $19.42 \mathrm{mg} / \mathrm{L}$ and $40.46 \mathrm{mg} / \mathrm{L}$ respectively. The Fe valued had exceeded the value of water quality standards, which should ideally not exceed $300 \mathrm{mg} / \mathrm{L}$. It was suspected that the area around Rawapening naturally have a high Fe content (>300 mg/L). Physicalchemical water parameters were projected using the Principal Component Analysis (PCA) based on sampling location and time of sampling, as shown in Figure 1.

The result of PCA analysis projected for water environment parameters showed no grouping of the three study sites. However, it appeared the grouping (clustering) when the PCA was projected based on the time of sampling, because a clear distinction between first, second and third sampling times were revealed. This grouping indicated that the values of physicochemical parameters of waters fluctuated from time to time. Seasonal change of the climate was suspected to influence change in seasonal physicochemical waters. Although the differences were relatively small, the PCA graph cauld still detect small changes, implying the effectiveness of the method.
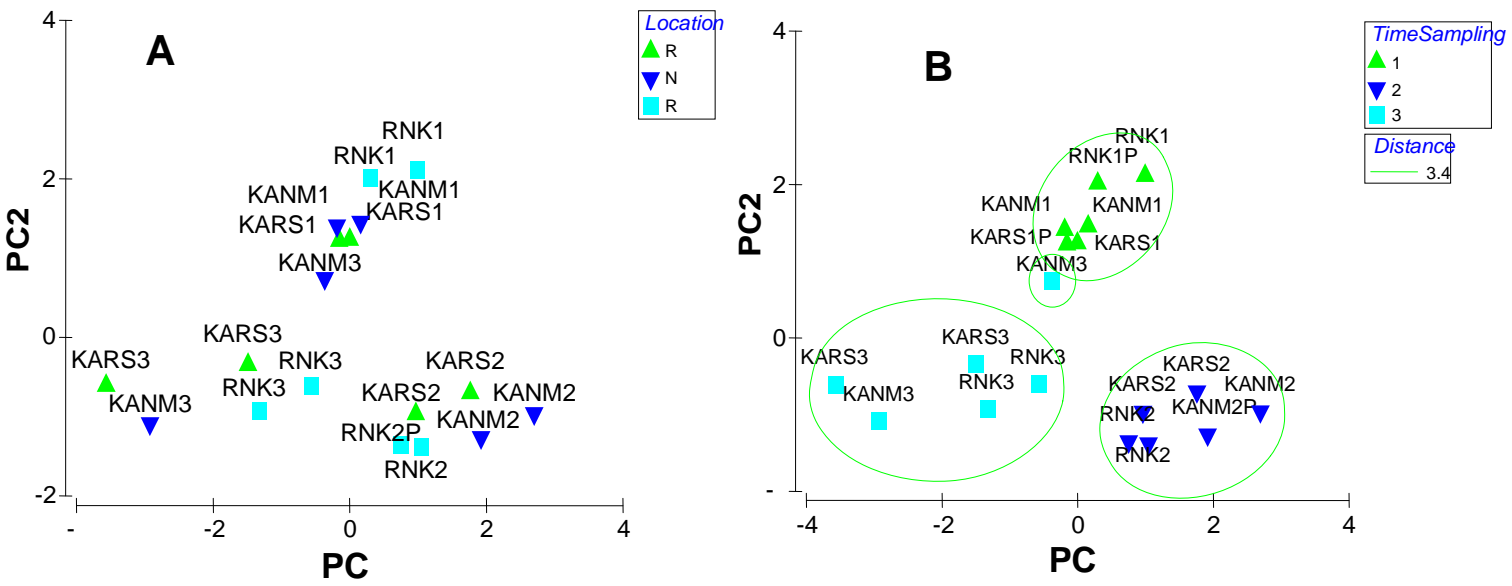

Figure 1. Graphic Principal Component Analysis (PCA), which was projected based on water environmental parameters for each location (A) and time of sampling (B). 
Proportion of species abundance in Location I was shown in Figure $2^{\mathrm{A}}$. The percentage of macrobenthic species abundance at location I was dominated by three families, which are Family Lumbrineridae (23.9\%), Family Capitellidae (22.9\%), and the Family Tubificidae $(14.7 \%)$. The three dominant taxa were known as opportunistic taxa that can dominate macrobenthic structure in sedimentary habitat that were susceptible to disturbance, particularly by organically enriched sediments (Putro et al., 2006; Fauchald, 1977; Pearson and Rosenberg, 1978).

The percentage composition of macrobenthic species abundance in location II was dominated by the Family Thiaridae (28.4\%), Turitellidae (25.6\%) and Tubificidae (15.4\%), as shown in Figure $2^{\mathrm{B}}$. The first two families were not recommended as opportunistic taxa, so their dominance did not indicate a disturbance/environmental change, except Tubificidae (Oligochaeta).

The existence of the family Tubificidae abundance at this location was an early indication of changes in the environment as the impact of

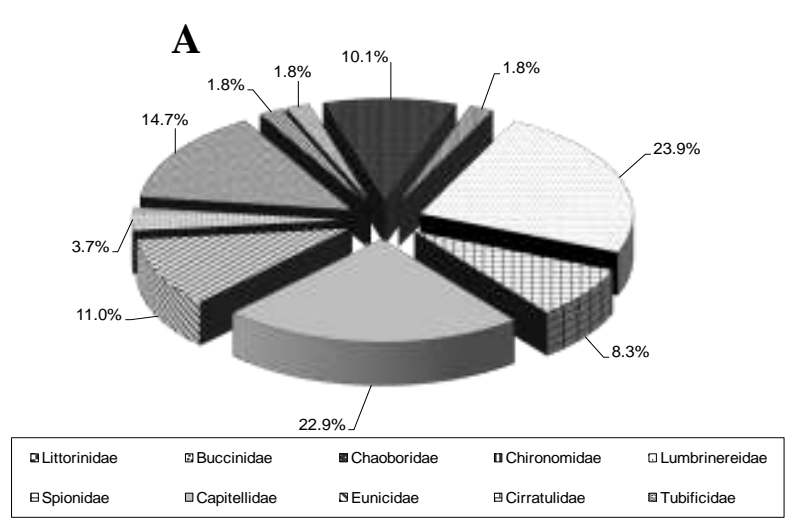

cage fish farming activities (Putro et al., 2013; Putro, 2014). The proportion of macrobenthic species abundance at location III was presented in Figure 3. The most dominating taxa of macrobenthic structure at location III was Family Thiaridae (52.7\%). As this family was considered not an opportunistic taxa, thus the dominance of the taxa did not indicate a disturbance/environmental changes on the site (referneces?). Result of two-way analysis of variance (ANOVA) shows the differences in abundance macrobenthic statistically significant between location I, II, and III $[F(2,183)=7461, p=.001]$, with the average size effect (partial eta squared $=.075$ ). Further test results using a Post Hoc (Tukey HSD) indicated a significant difference of macrobenthic abundance between location I $(\mathrm{M}=0: 56, \mathrm{SD}=0: 26)$ and II $(\mathrm{M}=0.75, \mathrm{SD}=$ $0: 39)$, and between location I and III ( $\mathrm{M}=$ $0.85, \mathrm{SD}=0: 40)$. The difference between the time $[F(2,183)=7461, p=.095]$ and interaction effect between time and location showed no significant difference $[\mathrm{F}$ $(4,183)=7461, p=.405]$.

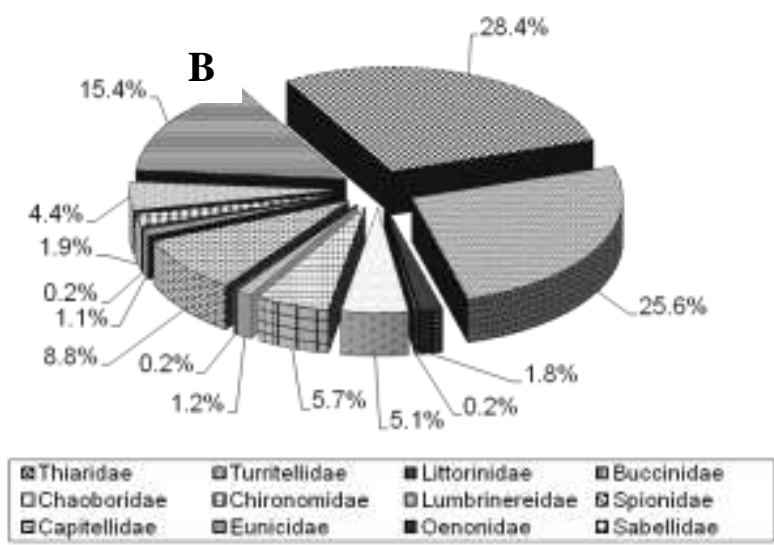

Figure 2. Proportion of the composition of macrobenthic species abundance at location I and II.

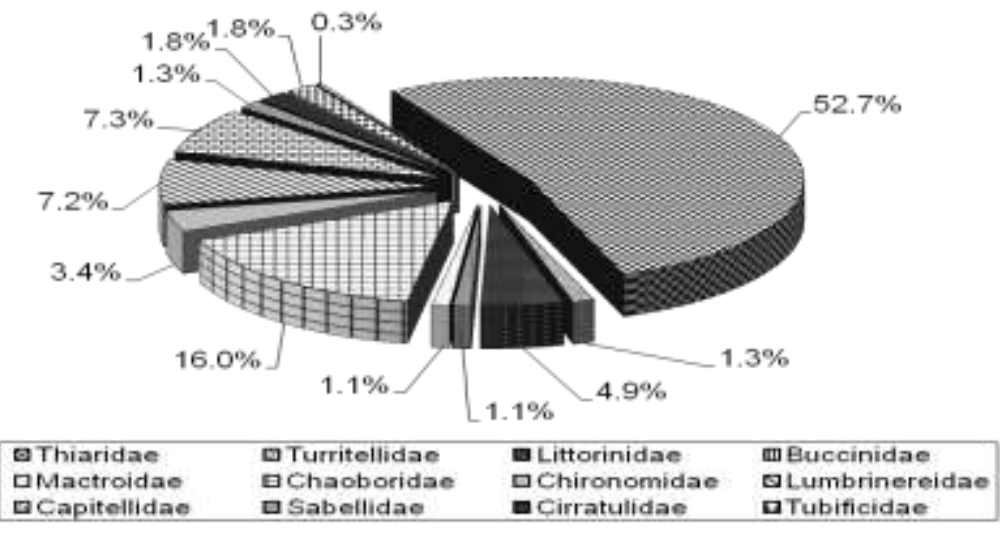

Figure 3. Proportion of the composition of macrobenthic species abundance at location III 
Similarity index of Pielou's Evenness ( $\mathrm{J}$ ') at the location I ranged from 0.95 to 0.98 , whilst location II and III ranged from 0.95 to 0.97 and 0.94 to 0.98 , respectively. Because the Pielou index determined how far an individual of the taxa is distributed evenly in a sample, thus the value of the index indicated a high level of similarity. This implied that species inhabiting the three sampling locations distributed evenly (Putro et al., 2006; Putro, 2007). Value of Shannon-Wiener diversity index $\left(\mathrm{H}{ }^{\prime}\right)$ at the ranged from 1.05 to 2.02 at location $\mathrm{I}$, from 1.97 to 2.65 at location II, and from 2.26 to 2.84 location III. Because the value of H'ranged from 0 to 5 , thus the diversity of macrobenthic assemblages at all three locations were considered low to moderate. According to Lee et al. in Fachrul (2007), the environmental quality criteria at the location I could be classified as moderately polluted areas, because the index $\mathrm{H}$ 'ranged from 1.0 to 1.5 , while location II and VIII were classified as undisturbed areas, because the value of the index $\mathrm{H}$ 'in both locations was greater than 2 . The low value of $\mathrm{H}$ 'in the location I might be caused by Stratified Double Net Cage (SDNC) activity. This means that the period of one year of environmental recovery in the farming area was not enough to let the environment to recover, as indicated by the low value of the diversity index $\left(\mathrm{H}^{\prime}\right)$.

Based on the position of all sampling stations on the graph of NMDS ordination, it could be seen that the position of the sampling stations projected on the graph were not clustered by time of sampling. This indicated that the structure of macrobenthos was not affected by time or season (Figure $4^{\mathrm{A}}$ ). However, if the ordination was projected based on sampling location (location I, II, and III), it appeared that position of the sampling stations projected on the graph of NMDS ordination were clustered by sampling location (Figure $4^{\mathrm{B}}$ ). This indicated that the structure of macrobenthos was more likely to be influenced by the different physical-chemical environment in the three sampling locations. This showed the tendency of differences in species composition between sites during the sampling period. The separation between the sites could also indicate that the macrobenthic assemblage is influenced by differences in structural characteristics of sediment and amount of organic matter, as has been reported by Snelgrove and Butman (1994) and Putro (2010).

Results from the analysis BESTBIOENV indicated a correlation between abiotic factors (physical and chemical parameters of water and sediment composition) that most influence on changes in the macrobenthos structure (biotic factors), as shown in Table 1. Based on the BESTBIOENV analysis, environmental factors that most influence on changes in the structure of macrobenthos were clay and silt $(\rho=0688)$. This is consistent with the results of research Weston (1988); Putro and Svane (2005) who concluded that the composition of sediments, mainly clay, silt, and fine sand were the main factors influencing the composition of macrobenthic animals.

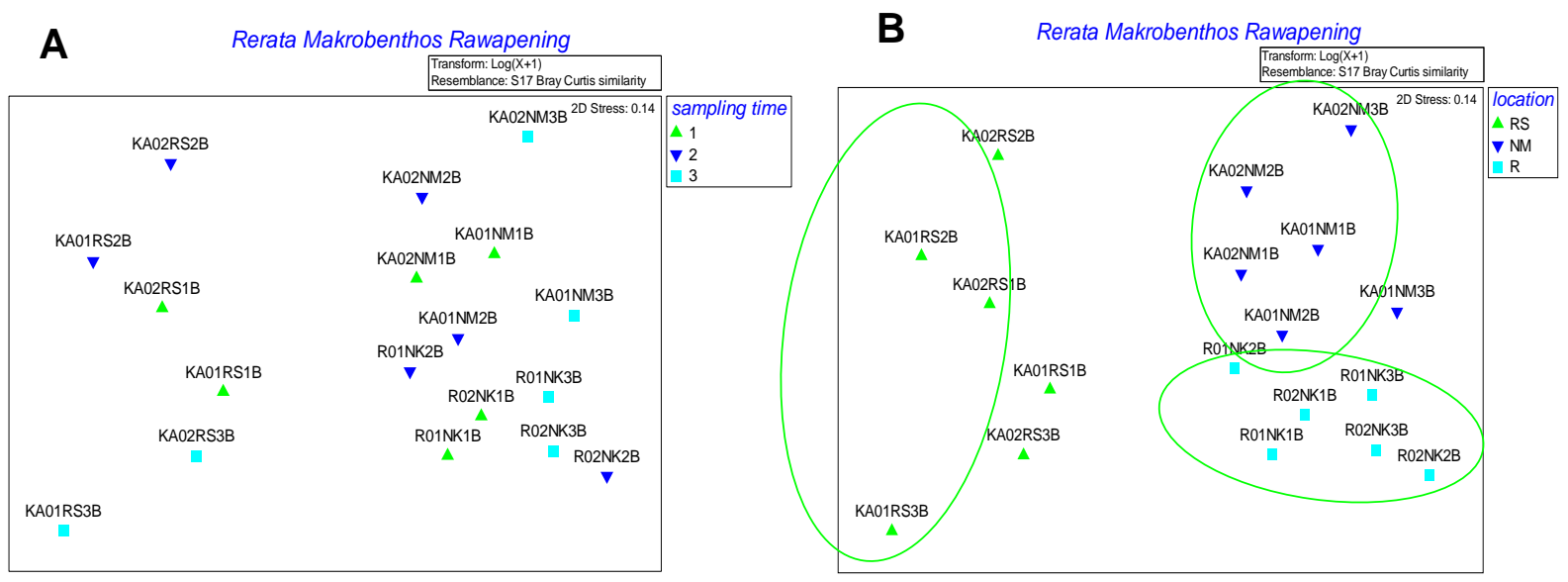

Figure 4. Ordination of Non-Metric Multi Dimensional Scaling (NMDS) projected based on data transformation of $\log (\mathrm{X}+1)$ of abundance of macrobenthos for each sampling time (A) and sampling location (B). 
Table 1. Result of BEST-BIOENV correlation analysis between abiotic factors (physical and chemical parameters of water and sediment). Description code environment variable: $1=\mathrm{pH}, 2=\mathrm{DO} ; 3=$ Turbidity; 4 = Conductivity; $5=$ Temperature; 6 = Brightness; $7=$ Gravel; $8=$ Sand netting`r; $9=$ Fine sand; 10 = clay and silt; $11=$ organic content.

\begin{tabular}{ccc}
\hline Number of Variable & Correlation Value $(\rho)$ & Abiotic Parameters Influencing Biotic Factors \\
\hline 1 & 0.688 & 10 \\
$\mathbf{2}$ & $\mathbf{0 . 6 5 2}$ & $\mathbf{1 , 1 0}$ \\
2 & 0.643 & 10,11 \\
3 & 0.631 & $1,10,11$ \\
4 & 0.619 & $1,7,10,11$ \\
4 & 0.606 & $1,8,10,11$ \\
2 & 0.602 & 7,10 \\
3 & 0.601 & $1,7,10$ \\
4 & 0.601 & $1,8,10$ \\
& 0.593 & $1,9-11$ \\
\hline
\end{tabular}

\section{Conclusions}

Based on the physical and chemical parameters of water and sediment, environmental condition of Lake Rawapening was within the normal range. Changes in community structure of macrobenthos were more influenced by locations (spatial) rather than temporal (time). Abiotic factors that most influence the structure of macrobenthos are clay and silt. Based on structure of macrobenthic assemblages, Location I can be categorized as moderately disturbed areas, Location II can be categorized as an initial level of disturbed areas, and Location III can be categorized as an area which is undisturbed (not disturbed) area.

\section{Acknowledgment}

The authors would like to thank to the DP2M-Directorate General of Higher Education (DIKTI) through Grant 'Hibah Kompetensi' Batch III 2014, and Grant "MP3EI" Batch II 2014 that have funded the research on the application of Stratified Double Net Cage (SDNC) to increase their production capacity and biomontoring of environmental quality adjacent SDNC based on macrobenthic assemblages towards sustainable aquaculture.

\section{References}

Clarke, K.R. and R.N. Gorley. 2006. Primer v6: User manual/tutorial. PRIMER-E Ltd. Plymouth, pp. 150-155.
Clarke, K.R. and R.M. Warwick. 2001. Change In Marine Comunities: An Approach To Statistical Analysis and Interpretation PRIMER-E Ltd, Playmouth.

Fachrul, M.F. 2007. Metode Sampling Bioekologi. Bumi Aksara, Jakarta.

Fauchald, K. 1977. The Polychaete Worms: Definitions and Keys to the Orders, Families, and Genera. Natural History Museum of Los Angeles County, Los Angeles

Pearson, T.H. and R. Rosenberg. 1978. Macrobenthic succession in relation to organic enrichment and pollution of the marine environment. Oceanography and Marine Biology Annual Review 16: 229311.

Putro, S.P., A. Sudaryono, R. Hariyati, and Suhartana. 2013. The Use of Multivariate and Graphical Methods in Assessing Environmental Disturbance: Temperate versus Tropical Regions. Journal of Environmental Science, Computer Science and Engineering and Technology (Online: www.jecet.org), 2 (4): 1175-1184.

Putro, S.P., A. Suherman, and R. Hariyati. 2010. Development of Aquaculture Environmental Management for the Improvement of Production Capacity for Sustainable Aquaculture Acitivites. The 1st Asea Uninet's Proceeding: The International Conference on Management of Innovation and Technology, Semarang, Indonesia, pp. B7.1-B7.6.

Putro, S.P. 2007. Spatial and temporal patterns of the macrobenthic assemblages in relation to environmental variables. Journal of Coastal Development, 10 (3): 15-22. 
Putro, S.P. dan Suhartana. 2008. Rehabilitasi dan optimalisasi pemanfaatan sumber daya alam kawasan rawapening dengan menerapkan manajemen lingkungan dan ecological engineering dalam upaya meningkatkan kesejahteraan masyarakat. Laporan KKN MG/L-DP2M DIKTI. Lembaga Penelitian Universitas Diponegoro. Semarang.

Putro, S.P. 2010. Environmental Quality Assessment of Fish Farming: Solutions Toward Sustainable Aquaculture. Lambert Academic Publishing (LAP), Saarbrucken. Germany.

Putro, S.P. 2014. Metode Sampling Penelitian Makrobenthos dan Aplikasinya: Penentuan Tingkat Gangguan Lingkungan Akuakultur. CV. Graha Ilmu, Yogyakarta.

Putro, S.P. and I. Svane. 2005. Effects of Fallowed Fish Farms on Macrobenthic Assemblages - A Full Year Assessment. Proceeding of Aquafin CRC2005Conference, Hobart, Australia.
Putro, S.P., I. Svane, and J. Tanner. 2006. Effects of fallowing on macrobenthic assemblages in sediments adjacent to southern bluefin tuna cages. Final Report of Aquafin CRC-Southern Bluefin Tuna Aquaculture: Evaluation of Waste Composition and Waste Mitigation. SARDI Aquatic Science, Adelaide.

Snelgrove, P.V.R. and C.A. Butman. 1994. Animal-sediment relationship revisited: cause versus effect. Oceanography and Marine Biology Annual Review, 32: 111177.

Weston, D.P. 1988. Macrobenthos-sediment relationships on the continental shelf off cape htteras, North Carolina. Continental Shelf Research, 8: 267-286. 